\title{
Naturalised geese in Europe
}

\author{
Naturaliserade gäss i Europa
}

HAKON KAMPE-PERSSON

\begin{abstract}
Besides elucidating which populations that ought to be counted as naturalised basic data of 69 national populations of naturalised Anser and Branta geese in Europe, and some local populations as well, were given. These populations, representing 15 different taxa, varied widely in size, from one pair to 35,000 pairs. Taking into account that recent population estimates are lacking for about one third of the national populations, at the same time as several populations have been in a phase of rapid growth since the late $1990 \mathrm{~s}$, it is no exaggeration to state that the
\end{abstract}

\section{Abstract}

total European post-breeding population of naturalised geese in 2009 numbered more than 800,000 individuals. More than $99 \%$ of these were made up of the three species Greater Canada Goose, Greylag Goose and Barnacle Goose.

Hakon Kampe-Persson, Pulmaṇi, Glūdas pagasts, Jelgavas novads, LV-3040, Latvia. E-mail: kampepersson@hotmail.com

\section{Introduction}

All but a few of the native goose populations wintering in Europe have increased markedly during the last half a century. During the same period geese that are found in the nature only thanks to Man, introduced deliberately or by mistake, have multiplied many times over, in number of species, in number of populations and in number of individuals. These birds, interchangeably referred to as feral, aliens, foreign, exotics, introduced, non-indigenous, non-native, sedentary, neozoans or naturalised, have gained attention by conservationists, managers and researchers during the last two decades. The increasing interest in these geese is due to their impact on biodiversity and humans (Hughes et al. 1999, Sol et al. 2005, Banks et al. 2008, Fox 2009). The biodiversity might be affected by introduction of alien genes, hybridisation, competition, disease transmission and habitat destruction, while the impact on humans might be economic (agriculture, aircraft, recreation areas and public health) or aesthetic. The impacts most often occupying managers of today are crop damage, fouling of park lawns, golf courses and public baths, and aggression by geese in recreation areas. Another concern is that negative experiences of naturalised geese among the public can spill over to their wild counterparts, resulting in a lower acceptance of geese in general.

A general interest in naturalisation has generated a large number of reports about alien, invasive, non-native and naturalised species during the last decade (e.g. Blair et al. 2000, Lever 2005). Several of these publications are available on internet, but many of them are, at least concerning geese, ambiguous. Already to the simple question whether or not a certain species breeds in a specific country, different reports often give contrary answers.

Summer surveys of naturalised geese were carried out in Britain in 1991 and 2000 (Delany 1993, Rowell et al. 2004), in the Republic of Ireland in 2000 (unpubl. data) and in the Netherlands in 2005 and 2009 (van der Jeugd et al. 2006, de Boer \& Voslamber 2010), while a similar survey in Britain in 2009, owing to lack of funding, only covered the two most numerous species (Carl Mitchell pers. comm.). Available knowledge of naturalised geese in Germany up to 2005 was published by Bauer $\&$ Woog (2008), and of invasive goose species in France up to 2006 by Dubois (2007). In other countries, several populations have been monitored on a local or regional level, often annually. In some countries, breeding data about at least some of the 
less numerous species have been collected by a national body, such as the Rare Breeding Birds Panel in the UK (www.rbbp.org.uk). However, which these monitors are and where they publish their results are often unknown to those searching the data.

Besides elucidating which populations that ought to be counted as naturalised, this report aims at giving basic data about all populations of naturalised Anser and Branta geese in Europe. The occurrence of Egyptian Goose Alopochen aegyptiaca in Europe up to 2009 was reported by Kampe-Persson (2010).

\section{Material and methods}

In 1995, a one-day conference on the introduction and naturalisation of birds was organised by the JNNC and the BOU. This led to a review of the process of establishment of such species and the terms that best describe their status (Holmes $\&$ Stroud 1995). That article was summarised by Holmes \& Simons (1996) in the following way: 'Terms such as 'exotic', 'alien' and 'non-native' describe the origins of the species concerned, whereas 'feral', 'introduced' and 're-established' describe the process by which establishment in the wild has occurred. The consensus at the conference was that 'naturalised' was a more appropriate allencompassing term for wild self-sustaining populations of such species, describing the outcome of the process. The term 'naturalised' can be accompanied by a qualifier explaining the origin of the species concerned to produce the following categories: (1) Naturalised feral: a domesticated species established in the wild. Note that mere keeping in captivity does not necessarily constitute domestication. The species must undergo some change in genotype, phenotype or behaviour in captivity. (2) Naturalised introduction: established species which would not occur without introduction by man. (3) Naturalised re-establishment: a successful re-establishment of a species in areas of former occurrence. Note that 're-established' is favoured over 'reintroduced'. The latter is often used to describe species which have been re-established in an area of former natural occurrence, following extinction. This usage is incorrect, however, since reintroduction implies that the species was introduced in the first place. (4) Naturalised establishment: establishment of a species which occurs but does not breed naturally in a given area e.g. a vagrant, passage migrant or winter visitor. Note that these terms are meaningless without some geographical reference."
Another three definitions of importance in this context were given by IUCN (1998): (1) Re-introduction: an attempt to establish a species in an area which was once part of its historical range, but from which it has been extirpated or become extinct. (Re-establishment is a synonym, but implies that the re-introduction has been successful). (2) Translocation: deliberate and mediated movement of wild individuals or populations from one part of their range to another. (3) Re-inforcement/Supplementation: addition of individuals to an existing population of conspecifics.

In a recent AEWA publication, Owen et al. (2006) defined a non-native taxon as "a species, sub-species or discrete geographical population that would not occur in an area without interference by man. This includes: (1) A taxon introduced as a breeding bird to a region where it normally only occurred in the non-breeding season; (2) A taxon introduced entirely outside of its previous known range; (3) A taxon imported and taken into captivity at a location outside of its normal range; (4) Domesticated taxa that have established in the wild, including domestic-type strains that have arisen by hybridisation between wild and domesticated individuals."

In spite of these definitions, it is far from always evident if a specific population should be counted as natural or naturalised. The problem can be to determine if a population was re-established or re-inforced, if a population was established by wild birds or by birds of captive ancestry, or how much contamination with genes from another taxa or discrete geographical population that is acceptable, if any at all. Currently, there is a tendency to treat more and more of the re-established and established populations as natural. Opinions about contamination with foreign genes are strongly divided, ranging from insistence on getting such birds eliminated to a want to do nothing at all. In this report, the question whether or not a specific population should be counted as naturalised is outlined under the different species headings. Note that occurrence of non-native genes did not qualify a population to be counted as naturalised.

A prerequisite of a naturalised population is that it is self-sustaining (Sol et al. 2005). In this report, all populations described as not being selfsustaining were mentioned in the text, while all others were included in Appendix. To prevent uncertainty whether any naturalised population had been overlooked, the aim was to include all breeding populations independent of size, also including one population that has ceased to exist. Populations 
are shown by nation, reflecting the normal way of monitoring. In some cases, local or regional populations are shown as well, partly when a country houses both natural and naturalised populations of a species, and partly when regional monitoring schemes motivate such a presentation. Information about which monitoring schemes that covers each of the populations is given. Up to three references to publications, giving essential information about establishment, population development, distribution, counts and/or estimates of number of breeding pairs and/or number of individuals, are listed for each population.

\section{Results and discussion}

The knowledge about naturalised goose populations varies greatly among countries and species, often also among local populations within a country (Appendix). This applies not only to the quality of the different population estimates, but also to how often populations are surveyed, if surveyed at all. Of national populations, $64 \%(n=69)$ have at least one estimate from either 2008 or 2009 . Taking into account that some countries, for instance UK and Germany, publish population estimates with several years delay, that proportion might increase to $77 \%$. On the other hand, one or two populations might be missing in Table 1, as the picture is incomplete for some of the countries.

In the Askania Nova Biosphere Reserve in southern Ukraine, founded by Friedrich von Falz-Fein in the 1880s, all Eurasian goose species are kept in semi-captivity (Alexander Mezinov in litt.). Each one of Greylag Goose, Snow Goose, Bar-headed Goose, Barnacle Goose and Greater Canada Goose produces more than 200 fledglings annually. Some of these fledglings are ringed and released. These releases have produced quite a number of recoveries (Zubko \& Havrilenko 2002); for instance, of Snow Geese from Norway (Lund 1966), Finland and France, while Greylag Geese have dispersed and restocked populations not only in Ukraine but also in Smolensk region, Vologodskaya region, Tverskaya region, Tyumenskaya region, Poland, Germany, Romania and Turkey. Geese breeding in Askania Nova were not included in Appendix.

The role of Askania Nova in the restoration of the Ukrainian Greylag Goose population is outlined based on data provided by Mikhail Banik. This exemplifies the importance of geographical scale, because while the Ukrainian population as a whole is re-inforced, some of the local populations might be naturalised. The Ukrainian population passed through a rather narrow bottleneck in the late 19th century and the first half of the 20th, when numbers were reduced to virtually single pairs at some sites, or dropped to zero in others. An opinion, manifested by Lysenko (1991), exists among Ukrainian ornithologists about the important role the Askania Nova population played in the restoration of the Ukrainian population. Though there are very few evidences, based on recoveries of ringed birds at breeding sites, that Askanian birds were founders of newly established sub-populations in different parts of Ukraine, Lysenko (1991) assumed that it was so. In particular, he argued that the re-inforcement process was responsible for the recovery of the Samarian-Orelian sub-population, the largest in Ukraine, and also, based on the behaviour of the birds in these groups, for those smaller sub-populations which breed in Eastern Syvash region, at Molochniy liman in Zaporozhye region and on ponds in the Zgar river flood-plain in the Vinnitsa region. During breeding season birds ringed in Askania Nova were recovered in Kherson region and Odessa region within the range of the Danubian-Dniester sub-population, in Kyiv region within the range of the north-western sub-population, and in Poltava region, Cherkassy region and Dnieperpetrovsk region within the range of the Samarian-Orelian sub-population. The size of the Danubian-Dniester sub-population is fairly stable at 10,000-16,000 individuals, the north-western population comprises about 1,000 breeding pairs, while the Samarian-Orelian sub-population has declined from 48,000 individuals in 1994 to only 12,000-18,000 since 2000 (Lysenko 2001, 2004). In the Kharkiv region, the breeding population declined from $610-635$ pairs in the mid-1990s to 310-330 pairs in 2005-2006 (Banik et al. 2008).

Countries not mentioned in Appendix probably lack populations of naturalised geese, but confirmation was only obtained from Andorra (Associació per a la Defensa de la Natura 2002), Belarus (Viktar Fenchuk in litt.), Bulgaria (Bulgarian National Rarities Committee 2009), Cyprus (www. birdlifecyprus.org), Estonia (Elts et al. 2009), Gibraltar (Garcia 2009), Hungary (Hadarics \& Zalai 2008, Sándor Faragó in litt.), Latvia (Kerus 2009), Liechtenstein (Georg Willi in litt.), Lithuania (Saulius Švažas in litt.), Macedonia (Metodija Velevski in litt.), Malta (www.birdlifemalta.org), Portugal (Matias et al. 2007), Slovakia (www. vtaky.sk) and Ukraine (Grishchenko 2004, Mikhail Banik in litt.). 


\section{Species accounts}

\section{Swan Goose Anser cygnoides}

All breeding records in Europe are of introduced birds. Seemingly, the Swan Goose often has difficulties in establishing itself. And in the Netherlands, the population is declining (Berend Voslamber in litt.). One reason can be the prevalence to hybridise with the Greylag Goose. In UK in 2000, a total of nine adult Swan Geese were found, but no less than 47 hybrids between Swan Goose and Greylag Goose (Rowell et al. 2004). In the Republic of Ireland, four hybrids between Swan Goose and Greylag Goose and 50 domestic geese were counted in the summer of 2000 (unpubl. data). Locally in South Sweden, introgression has taken place in the Greylag Goose (Kampe-Persson \& Lerner 2007).

\section{Taiga Bean Goose Anser fabalis}

In parts of the Swedish provinces Dalarna, Hälsingland and Härjedalen, where the Taiga Bean Goose was no longer breeding, a total of 376 colour-ring marked goslings, with Greater Canada Geese as foster parents, were released during the years 1974-1991 (von Essen 1982, Svensson et al. 1999). Main wintering area of the released birds was situated at Foteviken (own obs.), less than three kilometres from the venue of the GSG12. A total of 4-5 hybrids between Taiga Bean Goose and Greater Canada Goose have been reported from Sweden (Kampe-Persson \& Lerner 2007). It is not known, however, if these hybrids were a side effect of the release project, or the outcome of the Greater Canada Goose spreading into the breeding range of the Taiga Bean Goose. When the marked birds died, and the species ceased to winter at Foteviken, it became impossible to follow the birds. Whether the breeding of the species in the release areas (Svensson et al. 1999) is an outcome of the project or if these breeders are wild birds from adjacent areas is unknown. Most likely, this project was a successful re-inforcement.

\section{Tundra Bean Goose Anser serrirostris}

Introduction attempts in Hamburg in the 1950s and 1960s failed (Kreutzkamp 2003).

\section{Pink-footed Goose Anser brachyrhynchus}

Singly pairs bred in UK in 1980, 1991 and 1998 (Sharrock \& the Rare Breeding Birds Panel 1982, Delany 1993, Ogilvie \& the Rare Breeding Birds Panel 2000). Breeding records in northern Fennoscandia and northern Russia were of wild birds (Van Impe 2000, 2008, Irgens 2004), while at least one of the mates in each mixed pair (Sørensen \& Jensen 1991, Husby 1994, Birina 2005) most likely had captive ancestry. Small numbers of Pink-footed Geese of unknown captive or semi-captive origin have been reported from South Sweden (Elleström et al. 1996, Green et al. 1997). A free-flying population in Germany numbered 30 individuals but less than five breeding pairs during the period 2000-2005, but it is doubtful if these birds should be counted as breeding out of captivity (Bauer \& Woog 2008).

\section{White-fronted Goose Anser albifrons}

Introduction attempts of both albifrons and flavirostris in south-eastern Sweden in the 1930s (Berg 1937) resulted in at least some cases of breeding in the wild (Karlsson 1974). In UK, one pair of albifrons bred in 1991 and two pairs in 1998 (Delany 1993, Ogilvie \& the Rare Breeding Birds Panel 2000).

\section{Lesser White-fronted Goose Anser erythropus} In an area in Swedish Lapland, where the species still was breeding in low numbers (Andersson \& Holmqvist 2009), a total of 348 Lesser Whitefronted Geese were released during 1981-1999, with Barnacle Geese as foster parents (Andersson \& Larsson 2006). In all probability, the population breeding in Sweden today, the last remnant of a formerly abundant Scandinavian population, is a mixture of the original population and birds from the Swedish Lesser White-fronted Goose Project (Andersson \& Holmqvist 2007). These birds follow one of the traditional migration routes of the Scandinavian population, routes that were well separated from that of the North Fennoscandian population (Kampe-Persson 2009). Some of the released birds had very likely a hybrid ancestry (Ruokonen et al. 2007), but if any of these birds ever recruited into the breeding population is unknown. A way to catch and screen if any individual in the Scandinavian population has a hybrid ancestry was outlined by Ottvall (2008). As an unwanted side effect of the project some of the released males have paired up with Barnacle Goose females, and quite a number of hybrids have been produced (Kampe-Persson \& Lerner 2007). There is no known link, however, between the Swedish project and a pair of Lesser White-fronted Geese that bred in the Swedish province of Medelpad in 2006 (Allberg \& Marklund 2006), or of the pairs breeding in the Netherlands (Voslamber et al. 2010). The Scandinavian population of today has been treated as naturalised (Clavell et al. 2005, Jones et al. 2008), but rightly it should be counted as re-inforced. 
Greylag Goose Anser anser

After a population low in the first half of the 20th century translocations, introductions and re-introductions assisted in restoring the Greylag Goose in Europe (Kampe-Persson 2002). As several of the re-established populations nowadays are indiscernible from the wild ones, these projects turned out to be successful re-inforcements. In the Faroe Islands, for instance, two injured wild birds released in Tórshavn in the 1960s gave rise to a feral population, while breeding by Icelandic migrants did not become regular until the 1970s (Kampe-Persson 2002). The population increased to $2-10$ pairs in 1981 (Jensen 2006), 75 pairs in the mid-1990s (Asbirk et al. 1997), 80-100 pairs in the late 1990s, of which about one third was feral (Pennington 2000), 250 pairs in 2004 (Jensen et al. 2004) and 250-300 pairs in 2009, of which all were regarded as wild (Jens-Kjeld Jensen in litt.).

In South-east Iceland, a naturalised population was established in the mid-1950s, which increased to 50 individuals in 1962/1963, 100 in $1968 / 1969,500$ in 1990/1991, 860 in 2005/2006, 784 in 2008/2009 and 992 in 2009/2010 (Jóhann Óli Hilmarsson in litt.).

In Inner Oslofjord, both Norwegian and Swedish birds were released, establishing a mixed population of the two subspecies sylvestris and anser (Bergan 2000). If Greylag Geese breeding in the surroundings of Inner Oslofjord are wild birds, descendants of the released birds or a mix of these two is unknown (Arne Follestad in litt.). The counties situated closest to Inner Oslofjord are Østfold to the south-east and Vestfold, Telemark and AustAgder to the south-west. The species is breeding in Østfold, but nothing is known about in which numbers. There might be as many as $600-700$ pairs in Vestfold, while there are about 55 pairs breeding in the seabird reserves of Telemark. At least some of the geese breeding in Telemark ought to be wild, as the first breeding in this county was recorded in 1974, before the species started to breed in Inner Oslofjord. In Aust-Agder, where the first breeding was recorded in 1992, the breeding population is estimated to number $40-50$ pairs (Bengtson et al. 2009). Some of the pairs in Aust-Agder breed at fresh water, indicating occurrence of nominate birds in this county. However, if these birds originate from the naturalised population or from the Swedish is unknown (Arne Follestad in litt.).

Non-native birds were used also in other projects. In 1929, six Eastern Greylag Geese $A n$ ser anser rubrirostris were brought from India to south-eastern Sweden (Berg 1930, 1937). Nothing was heard about these birds thereafter, but translocations of eggs and birds from that part of Sweden to other Swedish sites took place more than once. All Greylag Geese in Scandinavia were reported as having orange bills in the middle of the 19th century (Nilsson 1858). In a recent study in South Sweden, all examined adults turned out to have either orange/pink or pink bills (Kampe-Persson 2003). Thus, rubrirostris genes are apparently well spread in the South Swedish Greylag Goose population of today. Another six rubrirostris geese were brought to the Zwin Reserve in Belgium in 1955 (Robyns De Schneidauer 1968). From Zwin the species spread over Belgium and the SW Netherlands. Taking ringing recoveries into account, birds from the Zwin population might have dispersed also to Denmark, Sweden and Germany. Other introductions of rubrirostris, using birds from Zwin, took place in England, the Netherlands and France (Sharrock 1976, Teixeira 1979, van den Bergh 1991, Riols 1994). The Zwin rubrirostris later hybridised with anser and gradually the rubrirostris characteristics disappeared from this population (Nilsson et al. 1999). However, do these disappearing characteristics refer to all traits, or only plumage? The bill colour in Dutch Greylag Geese is, for instance, similar to that in South Sweden (Berend Voslamber in litt). Genetic studies in the mid-1990s showed marked differences between breeders in the Netherlands and South Sweden (Blaakmer 1995).

In Lithuania, an unsuccessful re-introduction plan was implemented in the 1950s-1960s, with several geese of Russian origin kept in captivity, but none released (Saulius Švažas in litt.). Despite the fact that these geese were unable to fly and never left captivity, some of them entered the EURING database. By that, they have caused uncertainty whether the Lithuanian population of today is naturalised or wild. The Greylag Goose bred in the whole East Baltic region in the 19th century and the beginning of the 20th, but there were no records of breeding in Lithuania in the 1940s-1970s. Breeding was recorded in Lithuania again since 1980. That was the result of the overall range expansion of the species in the East Baltic region, with breeding recorded also in adjacent North-west Poland and in Latvia. At present the Lithuanian breeding population is estimated at about 150 pairs (Švažas et al. 1997, 1999, Kurlavičius 2006, Saulius Švažas in litt.). In Latvia, 2-3 released pairs bred in Lake Kanieris in 1972 and 1973, but no evidences of breeding were found thereafter (Mednis 1983).

Introduced birds in Italy are, in contrast to winter visitors, orange billed (Nicola Baccetti in litt.). 
Recently, pairs of the pink-billed wild population have colonized two wetlands in S and C Italy (Nicola Baccetti in litt.). In Spain, wild birds have been breeding since 2001, with at least four pairs in 2007 (Molina \& Lorenzo 2007, Molina et al. 2008, 2009). Occasional breeding at lower latitudes has been reported earlier however; in Algeria in the 19th century (Zedlitz 1914, Heim de Balzac \& Mayaud 1962), in Spain in 1993 (Moreno Gaztambide 1993) and in France in the 19th century and in the beginning of the 20th (Jourd 1935, Riols 1994).

The wintering population at Lac du Der-Chantecoq, east of Paris, is a special case of naturalisation, as those birds are impossible to count during the breeding season. Neck-collaring of 405 Greylag Geese in the Swedish province of Södermanland during 1984-1992 revealed that very likely all Greylag Geese wintering at Lac du Der-Chantecoq originated from Öster-Malma (Andersson et al. 2001). At Öster-Malma a population was re-established during 1970-75, mainly by taking eggs from south-eastern Sweden and using Greater Canada Geese as foster parents (Fabricius 1983). During the first strong winter with a thick snow cover, most probably 1978/1979 (Neubauer 1983), Greylag Geese of this newly re-established population were forced southwards from their former wintering quarters, situated somewhere around the SW Baltic Sea (Fabricius 1983), and by chance they found Lac du Der Chantecoq. If all Greylag Geese wintering at this site nowadays originate from Öster-Malma is unknown however.

As Camargue is situated well outside the traditional migration routes of the species (KampePersson 2002), also that wintering population is very likely mainly made up of naturalised birds. The number wintering at Camargue has increased from less than 50 birds in the 1980 s to 2,389 in 2008 (Desnouhes et al. 2003, Deceuninck et al. 2009).

That Greylag Geese are unafraid of humans and breed in an urban setting do not by necessity mean that they are naturalised. The well-studied population at Utterslev Mose in Copenhagen, sometimes referred to as naturalised (Rutschke 1997), is fully wild (Kampp \& Preuss 2005). The Greylag Goose has bred at Utterslev Mose at least since 1914, long before the surroundings were urbanised (Jensen 1975).

Soepgans is in the Netherlands used as a generic term for free-flying individuals of domesticated forms of the Greylag Goose, hybrids between such geese and both the Greylag Goose and all other goose species, and all individuals of the domesti- cated forms of the Swan Goose as well (van der Jeugd et al. 2006). In Appendix, they are all reported as Anser anser domesticus. To make figures comparable the same definition was used for data from UK, Ireland and Belgium. The Soepgans is widely distributed in Belgium, found in $42 \%$ of the squares of the Flemish Breeding Atlas (Vermeersch et al. 2004), but no good population estimate exists (Anselin \& Devos 2005, van der Jeugd et al. 2006).

\section{Bar-headed Goose Anser indicus}

All breeding records in Europe are of introduced birds. In Norway, the species has bred since the 1950s without becoming established (Gederaas et al. 2007). A small flock in Stavanger produced young every year from the 1950s until the birds disappeared from the area in 1972. One pair bred at Tau during 6-8 years in the 1970s. One female disappeared from Oslo in the early 1970s and returned in late summer with three fledglings. Singly pairs bred in Sør-Trøndelag in 1992 and in Møre og Romsdal in 1994. Several individuals have been observed during the last decade, especially in Mid-Norway and southwards, and the population was in 2007 estimated at 10-49 individuals. Introduction attempts in south-eastern Sweden in the 1930s (Berg 1937) resulted in at least some cases of breeding in the wild (Curry-Lindahl 1963). In Finland, up to two breeding pairs from a population of about 25 birds succeeded in raising young in a good year (Lever 2005, by referring to Blair et al. 2000). The species is still breeding in Finland (www.lintuatlas.fi). Lack of confirmation from Finland indicates, however, that these birds probably do not form a self-sustaining population. Lever (2005, by referring to Blair et al. 2000) stated that ten sub-populations have occurred in ten provinces in Italy, in three of which successful breeding has been recorded. This must be a confusion of species or countries, however, because there are no breeding records in Italy and only a few records of 1-4 individuals in the northern part of the country (Nicola Baccetti in litt., Camilla Gotti in litt.).

\section{Snow Goose Anser caerulescens}

Occasionally, wild birds cross the Atlantic (Blankert 1980, Sadura \& Cooke 1982), but all breeding records in Europe are regarded as being of introduced birds. Statements that the species was fairly common in the East Atlantic flyway in the Middle Ages (Magnus Gothus 1555) were caused by confusion with the Northern Gannet Morus bassanus. In Norway, the species ceased to breed in Inner Oslofjord after having bred there 1981-2006 (Ber- 
gan 2010). Introduction attempts in south-eastern Sweden in the 1930s (Berg 1937) resulted in at least some cases of breeding in the wild (CurryLindahl 1963). Later, breeding was reported from Västerås 1976-1977 and 1980, Strömsholm 1977 and 1980, Hallstahammar 1980, Lake Mälaren 1985, province of Blekinge 1989, province of Östergötland 1993 and 1996-1997, and probably in the province of Södermanland 1987 (SOF 1990, 2002). The species has also bred a few times in Finland (Alström et al. 1992).

\section{Ross' Goose Anser rossii}

All breeding records in Europe are of introduced birds.

\section{Emperor Goose Anser canagica}

All breeding records in Europe are of introduced birds.

\section{Barnacle Goose Branta leucopsis}

Without releases and escapes from captivity, there had, in all probability, been no breeding colonies of the Barnacle Goose in temperate areas today. Nine local populations and one regional, each linked to a nearby source of free-flying captive birds, were included in Appendix. The largest of these ten, on the Danish island Saltholm, is situated only 12 kilometres from Malmö. It has not been proven that the population on Saltholm was founded by escapes however. In contrary, they are normally treated as a wild population resulting of an expansion of the populations on Gotland and Öland (Timme Nyegaard in litt.). Considering the long distances of dispersal documented among free-flying captive Barnacle Geese (Bengtsson 2007), other local populations than the afore-mentioned nine could have been included in Appendix as well, together with populations that were deliberately established. The first Swedish breeding record, for instance, in the province of Härjedalen in 1952 (Burman 1957), was of birds that had escaped from captivity in Scotland (Berry 1951). An ever increasing number of free-flying captive birds from the 1960s onwards correlates fairly well with the establishment of local breeding populations in the Baltic Sea region (Bengtsson 2007).

Barnacle Geese breeding in Iceland, on the Swedish islands of Gotland and Öland, in Estonia and along the German coast are often counted as wild. As these colonies have no known linkage to any source of free-flying captive birds, they were not included in Appendix, but well in Table 1. In Iceland, the species has bred in very small numbers since 1964, and in 1999, the total population was estimated at 80-90 birds, including eight breeding pairs (Náttúrfræðistofnun Íslands 2000). In Öland, the breeding population increased from one pair in 1982 (Fritz 1983) to about 780 in 2005 (Feige et al. 2008), while in Gotland, the numbers increased from one pair in 1971 (Beinert 1982) to 4713 in 2002 followed by a decrease to 3285 in 2008 (Lerner 2009). The Estonian population increased from one pair in 1981 to 189 in 1999 followed by a decrease to 80 in 2006 (Leito \& Truu 2008). After the first breeding in 1988 the German "wild" population increased to 160 pairs in 2005 (Bauer \& Woog 2008).

\section{Lesser Canada Goose Branta hutchinsii}

Occasionally, wild birds cross the Atlantic (Vinicombe 2007), but all breeding records in Europe are regarded as being of introduced birds. Due to mixing and hybridisation with Barnacle Geese the species is hard to count in the Netherlands (Berend Voslamber in litt.).

\section{Greater Canada Goose Branta canadensis}

All breeding records in Europe are regarded as being of introduced birds, but there are some indications of transatlantic dispersal (Kampe-Persson MS).

The size of the Swedish post-breeding population was estimated by combining hunting statistics (www.jagareforbundet.se) and mid-winter counts (Nilsson 2009), taking into account that parts of the Swedish population winter south of the Baltic Sea, some flocks are overlooked during the counts and parts of the Norwegian and Finnish populations most likely winter in Sweden. The latest Finnish estimate concerns the years 2006-2009. Coastal data came from the Finnish Archipelago Bird Census, while the main sources of inland data were waterfowl monitoring and the third Bird Atlas survey of Finland (Markku Mikkola-Roos in litt.).

Breeding of singly pairs, without giving rise to a population, has been reported at Lake Ladoga (Medvedev 1992) and in Latvia in 1991 (Ādamsons \& Roze 1995). The small flock in Italy is believed not to be self-sustaining (Nicola Baccetti in litt.).

\section{Hawaian Goose Branta sandvicensis}

There are no breeding records, but 13 individuals were counted in the Republic of Ireland in 2000 (unpubl. data) and 11 in the Netherlands in July 2009 (de Boer \& Voslamber 2010). 
Table 1. Total number of naturalised Anser and Branta geese in Europe. When only a figure for either number of pairs or number of birds was available for a population, the other figure was calculated using the same ratio between number of pairs and number of birds as in similar populations. Before doing such calculations, some of the populations were updated with data not included in Appendix. When only number of adults at onset of breeding was given for a population, a figure for the size of the post-breeding population was calculated.

Totala antalet naturaliserade Anser- och Branta-gäss i Europa. I de fall då endast en av uppgifterna för antalet par och antalet individer fanns tillgänglig för en population beräknades den andra uppgiften genom att tilllämpa samma förhållande mellan antalet par och antalet individer som i liknande populationer. Innan dylika beräkningar gjordes uppdaterades en del av populationerna med uppgifter som inte inkluderats i Appendix. I de fall när endast antalet adulter vid häcksäsongens början angetts gjordes en beräkning av populatioens storlek vid häcksäsongens slut.

\begin{tabular}{lcc}
\hline Taxon & $\begin{array}{c}\text { Number of pairs } \\
\text { Antal par }\end{array}$ & $\begin{array}{c}\text { Number of individuals } \\
\text { Antal individer }\end{array}$ \\
\hline Anser cygnoides & $175-180$ & 600 \\
Anser serrirostris & 2 & 5 \\
Anser brachyrhynchus & $752-755$ & 14 \\
Anser albifrons albifrons & 1 & 3000 \\
Anser albifrons flavirostris & 3 & 5 \\
Anser erythropus & 55,000 & 7 \\
Anser anser & $5000-6000$ & 315,000 \\
Anser anser domesticus & $168-193$ & 24,000 \\
Anser indicus & 19 & 750 \\
Anser caerulescens & 1 & 161 \\
Anser rossii & 7 & 2 \\
Anser canagica & 20,000 & 170 \\
Branta leucopsis & 200 & 100,000 \\
Branta hutchinsii & $56,000-63,000$ & 500 \\
Branta canadensis & $137,000-145,000$ & $346,000-356,000$ \\
Total & & $790,000-800,000$ \\
\hline
\end{tabular}

\section{Brent Goose Branta bernicla}

There are no breeding records, but in UK, nine birds were counted in the summer of 1991 (Delany 1993 ) and four in the summer of 2000 (Rowell et al. 2004), while 28 were found in the Netherlands in July 2009 (de Boer \& Voslamber 2010).

\section{Red-breasted Goose Branta ruficollis}

Singly pairs bred in Ukraine in 1998 (Domashevsky 2001), Germany in 2002 (Brandt \& Hadasch 2002) and UK in 2003 (Holling \& the Rare Breeding Birds Panel 2007).

\section{Monitoring}

The quality of the different population estimates was not given in Appendix. In most cases, such information can be found among the references listed under Sources, or it was expressed in mails to the author. An examination of that information makes it possible to draw some general conclusions about monitoring of naturalised geese on a national level.
As long as the populations are quite small or breed in a limited number of well defined colonies, they can be monitored by gathering breeding data centrally. For that to work efficiently, especially when relying on volunteers, a strong incentive to collect and report such data must prevail. One way of attaining that is by regular feedbacks to those collecting the field data, for instance by publishing annual reports within six months of the field season. When the populations grow too large or become too scattered for that kind of monitoring, it is time to organise large-scale summer surveys. Experiences of such surveys from UK and the Netherlands can be used when deciding how frequently such surveys ought to be carried out. Some of the most numerous populations can also be monitored by counts during the non-breeding season, even though such count data normally only give minimum numbers. Often, however, count data can be used for the calculation of population indices, which in turn can be used for the calculation of population estimates. Another option, sometimes practised, is to base a Breeding Atlas on both qualitative and quantitative data. 


\section{Total numbers in Europe}

Taking into account that recent population estimates are lacking for about one third of the national populations (Appendix), at the same time as several populations have been in a phase of rapid growth since the late 1990s, it is no exaggeration to state that the total European post-breeding population of naturalised geese in 2009 numbered more than 800,000 individuals (Table 1). More than $99 \%$ of these were made up of the three species Greater Canada Goose, Greylag Goose and Barnacle Goose. To the numbers given in Table 1 should be added an unknown number of hybrids. Hybrid reports are available from four countries; 318 hybrids in Great Britain in 1991 (Delany 1993) and 210 in 2000 (Rowell et al. 2004), 229 in Germany in 1998 (Randler 2000), 310-327 in Sweden in 2005 (Kampe-Persson \& Lerner 2007) and three breeding pairs (Greylag Goose x Greater Canada Goose x Barnacle Goose) in Faroe Islands in 2009 (Jens-Kjeld Jensen in litt.).

\section{Acknowledgements}

For providing published and unpublished data I am indebted to Hólmfríður Arnardóttir, Nicola Baccetti, Mikhail Banik, Morten Bergan, André Burnel, Olivia Crowe, Michael Dvorak, Sándor Faragó, Viktar Fenchuk, Arne Follestad, Camilla Gotti, Peter Greenstreet, Jens Hartmann, Jóhann Óli Hilmarsson, Simon Hinrichs, Hans-Joachim Hoff, Jacques Van Impe, Kjell Isaksen, Henning Jensen, Jens-Kjeld Jensen, Verena Keller, André Konter, Patric Lorgé, Alexander Mezinov, Markku Mikkola-Roos, Leif Nilsson, Timme Nyegaard, Michal Podhrazský, Ole Reitan, Éric Roualet, Wojciech Solarz, Saulius Švažas, Metodija Velevski, Milan Vogrin, Berend Voslamber, Georg Willi and Friederike Woog. Mikhail Banik, Morten Bergan, Arne Follestad, Jacques Van Impe, Jens-Kjeld Jensen, Patric Lorgé, Timme Nyegaard and Wojciech Solarz gave valuable comments on draft versions.

\section{References}

Ādamsons, V. \& Roze, V. 1995. Pirmais Kanādas zoss Branta canadensis ligzdošanas gadijums Latvijā. Putni dabā 5(2): 98 .

Allberg, B. \& Marklund, I. 2006. Fjällgås - ny häckfågelart för landskapet. Fåglar i Medelpad 29(3/4): 19-21.

Alström, P., Colston, P. \& Lewington, I. 1992. En fälthandbok över sällsynta fåglar i Europa. Domino Books, Jersey.

Andersson, Å., Follestad, A., Nilsson, L. \& Persson, H. 2001. Migration patterns of Nordic Greylag Geese Anser anser. Ornis Svecica 11: 19-58.
Andersson, Å. \& Holmqvist, N. 2007. Lyckat år för fjällgässen. Svensk Jakt Nyheter 10/2007: 4.

Andersson, Å. \& Holmqvist, N. 2009. Fjällgässen i Lappland. Fåglar $i$ Västerbotten 34: 26-28.

Andersson, A. \& Larsson, T. 2006. Reintroduction of Lesser White-fronted Goose Anser erythropus in Swedish Lapland. Pp. 635-636 in Waterbirds around the world (Boere, G.C., Galbraith, C.A. \& Stroud, D.A., eds.). The Stationary Office, Edinburgh.

Anselin, A. \& Devos, K. 2005. Winter counts of feral geese in Flanders, with special attention given to the Canada Goose Branta canadensis. Oriolus 71 (Supplement): 90102. (Flemish with English summary).

Asbirk, S., Berg, L., Hardeng, G., Koskimies, P. \& Petersen, Æ. 1997. Population sizes and trends in the Nordic Countries 1978-1994. TemaNord 1997: 614. Nordic Council of Ministers, Copenhagen.

Associació per a la Defensa de la Natura 2002. Atlas of the Breeding Birds of Andorra. Andorra la Vella. (Catalan with English summaries).

Banik, M.V., Nadtochiy, A.S. \& Vergeles, I. 2008. The status of the Greylag Goose Anser anser breeding population in the Kharkiv region, Ukraine. Vogelwelt 129: 360-362.

Banks, A.N., Wright, L.J., Maclean, I.M.D., Hann, C. \& Rehfisch, M.M. 2008. Review of the Status of Introduced Non-Native Waterbird Species in the Area of the AfricanEurasian Waterbird Agreement: 2007 Update. BTO Research Report No. 489, 148 pp. British Trust for Ornithology, Thetford.

Bauer, H.-G. \& Woog, F. 2008. Non-native and naturalised bird species (neozoa) in Germany, part I: occurrence, population size and status. Vogelwarte 46: 157-194. (German with English summary).

Beinert, R. 1982. De vitkindade gässen på Gotland. Pp. 5760 in De svenska gässen: förekomst, ekologi, betesskador, jakt och vård. (Svensson, S., ed.). Vår Fågelvärld, supplement 9, Stockholm.

Bengtson, R., Johnsen, A., Selås, K.O. \& Steel, C. 2009. Hekkefugleatlas for Aust-Agder 1995-2004. Fugler i Aust-Agder, supplement 1. Norsk Ornitologisk Forening avdeling Aust-Agder, Arendal.

Bengtsson, K. 2007. Vitkindad gås - det rysk/baltiska beståndets expansion. Anser 46: 137-162.

Berg, B. 1930. De liefdesgeschiedenis van een wilde gans. H.P. Leopolds Uitgeversnij N.V., The Hague.

Berg, B. 1937. Mina försök med vildgäss. P.A. Norstedt \& Söners Förlag, Stockholm.

Bergan, M. 2000. Sjøfuglene i indre Oslofjord. Toppdykker'n 23: $154-162$.

Bergan, M. 2010. Snøgåsa som hekkefugl i Norge - en epoke er over. Vår Fuglefauna 33: 66-72.

Bergh, L.M.J. van den 1991. Hoeveel Grauwe Ganzen broeden er in Nederland? Het Vogeljaar 39: 117-120.

Berry, J. 1951. Migration to North Norway of Barnacle Geese which had been bred in Scotland. Pp. 339-340 in Proceedings of the $X^{\text {th }}$ International Ornithological Congress, Uppsala 1950 (Hörstadius, S., ed.). Almqvist \&Wiksell, Uppsala.

Birina, K. 2005. Blandningspar av kortnebbgås och tundragås med hekkeforsøk i Lofoten. Vår Fuglefauna 28: $158-160$.

Blaakmer, K. 1995. Genetic variation within the West European population of the Greylag goose (Anser anser). Sub- 
fase III Report, 27 pp. Animal Ecology and Population Genetics, University of Groningen.

Blair, M.J., McKay, H., Musgrove, A.J. \& Rehfisch, M.M. 2000. Review of the status of introduced non-native waterbird species in the agreement area of the African-Eurasian Waterbird Agreement. BTO Research Report 229. BTO, Thetford.

Blankert, J.J. 1980. Lesser Snow Goose from Canada in Netherlands. Dutch Birding 2: 52.

Boer, V. de \& Voslamber, B. 2010. Hoeveel overzomerende ganzen telt Nederland? SOVON-Nieuws 23(2): 3-4.

Brandt, T. \& Hadasch, J. 2002. Die erste Freilandbrut der Rothalsgans Branta ruficollis in Deutschland. Limicola 16: $265-270$.

Bulgarian National Rarities Committee (BUNARCO) 2009. List of the Birds Recorded in Bulgaria. Acta Zoologica Bulgarica 61: 3-26.

Burman, E. 1957. A case of breeding Barnacle-Goose (Branta leucopsis) in the province of Härjedalen, northern Sweden. Vår Fågelvärld 16: 48+58. (Swedish with English summary).

Clavell, J., Copete, J.L., Gutiérrez, R., de Juana, E. \& Lorenzo, J.A. 2005. List of the birds of Spain. Sociedad Española de Ornitología, Madrid.

Curry-Lindahl, K. (ed.) 1963. Våra Fåglar i Norden. Vol. 4. $2^{\text {nd }}$ ed. Natur och Kultur, Stockholm.

Deceuninck, B., Maillet, N., Ward, A., Dronneau, C. \& Maheo, R. 2009. Census of Anatidae and coots wintering in France - January 2008. Report, 46 pp. Ligue pour la Protection des Oiseaux, Rochefort. (French with English summary).

Delany, S. 1993. Introduced and escaped geese in Britain in summer 1991. British Birds 86: 591-599.

Desnouhes, L., Pichaud, M., Le Clainche, N., Mesleard, F. \& Giroux, J.-F. 2003. Activity budget of an increasing wintering population of Greylag Geese Anser anser in southern France. Wildfowl 54: 39-49.

Domashevsky, S.V. 2001. [Ornithofauna of the Regional Landscape Park "Granitno-stepove Pobuzhzhya" and adjacent territories.] Zapov. sprava v Ukraini 7(2): 23-29. (Russian).

Dubois, P.J. 2007. Invasive bird species in France in 2006. Ornithos 14: 329-364. (French with English summary).

Elleström, O., Green, M., Larsson, H., Malmhagen, B., Ottvall, R., Rellmar, M. \& Råberg, L. 1996. Fåglar i Skåne 1995. Anser, supplement 39, Lund.

Elts, J., Kuresoo, A., Leibak, E., Leito, A., Leivits, A., Lilleleht, V., Luigujõe, L., Mägi, E., Nellis, R., Nellis, R. $\&$ Ots, M. 2009. Status and numbers of Estonian birds, 2003-2008. Hirundo 22: 3-31.

Essen, L. von 1982. Försöksverksamhet med uppfödning och utplantering av sädgås. Pp. 105-108 in De svenska gässen (Svensson, S., ed.). Vår Fågelvärld, supplement 9, Stockholm.

Fabricius, E. 1983. The Canada Goose in Sweden. PM 1678. Statens Naturvårdsverk, Stockholm. (Swedish with English summary).

Feige, N., van der Jeugd, H.P., van der Graaf, A.J., Larsson, K., Leito, A. \& Stahl, J. 2008. Newly established breeding sites of the Barnacle Goose Branta leucopsis in Northwestern Europe - an overview of breeding habitats and colony development. Vogelwelt 129: 244-252.

Fox, A.D. 2009. What makes a good alien? Dealing with the problems of non-native wildfowl. British Birds 102: 660-679.

Fritz, Ö. 1983. Fågelrapport för Öland 1982. Calidris 12: 125-59.

Garcia, E. 2009. The Gibraltar bird list. The Gibraltar Ornithological \& Natural History Society.

Gederaas, L., Salvesen, I. \& Viken, Å. (eds.) 2007. Norwegian Black List-Ecological Risk Analysis of Alien Species. Artsdatabanken, Norway.

Green, M., Larsson, H., Malmhagen, B., Ottvall, R., Rellmar, M., Råberg, L. \& Segergren, J. 1997. Fåglar $i$ Skåne 1996. Anser, supplement 40, Lund.

Grishchenko, V. 2004. Checklist of the birds of Ukraine. Berkut 13: 141-154.

Hadarics, T. \& Zalai, T. 2008. An annotated list of the birds of Hungary. Magyar Madártaniés Természetvédelmi Egyesület, Budapest. (Hungarian with English summaries).

Heim de Balzac, H. \& Maynaud, N. 1962. Les Oiseaux du Nord-Ouest de l'Afrique. Lechevalier, Paris.

Holling, M. \& the Rare Breeding Birds Panel. 2007. Non-native breeding birds in the United Kingdom in 2003, 2004 and 2005. British Birds 100: 638-649.

Holmes, J.S. \& Simons, J.R. (eds.) 1996. The Introduction and Naturalisation of Birds. The Stationary Office, London.

Holmes, J.S. \& Stroud, D.A. 1995. Naturalised birds: feral, exotic, introduced or alien? British Birds 88: 602-603.

Hughes, B., Kirby, J. \& Rowcliffe, J.M. 1999. Waterbird conflicts in Britain and Ireland: Ruddy Duck Oxyura jamaicensis, Canada Geese Branta canadensis, and Cormorants Phalacrocorax carbo. Wildfowl 50: 77-99.

Husby, M. 1994. Kortnebbgås hekket i lag med kanadagås i Hammervatnet i 1994. Trøndersk Natur 21: 78.

Impe, J. Van 2000. A forgotten breeding record of the Pinkfooted Goose Anser brachyrhynchus on the European Continent. Oriolus 66: 129-131. (Flemish with English summary).

Impe, J. Van 2008. Important changes in the breeding range of wild geese (Anser sp. and Branta sp.) in the North of European Russian. Alauda 76: 11-22. (French with English summary).

Irgens, M. 2004. Første hekkefunn av kortnebbgås på det norske fastlandet. Vår Fuglefauna 27: 110-111.

IUCN 1998. Guidelines for Re-introductions. IUCN, Gland \& Cambridge.

Jensen, H. 1975. Gray Lag Studies 3: The population in Utterslev Mose and Kagsmosen, Copenhagen. Danske Fugle 9: 81-85. (Danish with English summary).

Jensen, J.-K. 2006. Greylag Geese in the Faroe Islands. GooseNews 5: 7.

Jensen, J.-K., Bloch, D. \& Olsen, B. 2004. Liste over Fugle der er set på Fcerøerne / List of Birds seen in the Faroe Islands. $2^{\text {nd }}$ ed. Føroya Náttúrugripasavn, Tórshavn.

Jeugd, H.P. van der, Voslamber, B., van Turnhout, C., Sierdsema, H., Feige, N., Nienhuis, J. \& Koffijberg, K. 2006. Overzomerende ganzen in Nederland: grenzen aan de groei? Sovon-onderzoeksrapport 2006/02. SOVON Vogelonderzoek Nederland, Beek-Ubbergen. (Dutch with English summary).

Jones, T., Martin, K., Barov, B. \& Nagy, Sz. (compilers) 2008. International Single Species Action Plan for the Conservation of the Western Palearctic Population of the Lesser White-fronted Goose Anser erythropus. AEWA 
Technical Series No. 36. Bonn, Germany.

Jourd, H. 1935. Sur la nidification dune Oie cendrée $A n$ ser anser dans notre département des Vosges. Alauda 3: 423-425.

Kampe-Persson, H. 2002. Anser anser Greylag Goose. BWP Update 4: 181-216.

Kampe-Persson, H. 2003. Variation in bill colour among Greylag Geese Anser anser breeding in south-west Scania. Ornis Svecica 13: 63-66.

Kampe-Persson, H. 2009. Vart flyttade de svenska fjällgässen? Fåglar i Västerbotten 34: 29-43.

Kampe-Persson, H. 2010. Occurrence of Egyptian Goose Alopochen aegyptiaca in Europe. Goose Bulletin 10: 34-37.

Kampe-Persson, H. MS. On transatlantic dispersal in the Greater Canada Goose Branta canadensis.

Kampe-Persson, H. \& Lerner, H. 2007. Occurrence of hybrid geese in Sweden - a conservation problem? Ornis Svecica 17: 154-186.

Kampp, K. \& Preuss, N.O. 2005. The Greylag Goose of Utterslev Mose. A long-term population study of wild geese in an urban setting. Dansk Ornitologisk Forenings Tidskrift 99: 1-78.

Karlsson, J. 1974. Birds introduced in Sweden. Anser 13: 99-106. (Swedish with English summary).

Kerus, V. 2009. Ar mēnesi uz sparniem (II). Medības. Makškerēšana. Daba 10/2009: 24-26.

Kestenholz, M., Heer, L. \& Keller, V. 2005. Non-indigenous bird species established in Europe - a review. Der Ornithologische Beobachter 102: 153-180. (German with English summary).

Kreutzkamp, I. 2003. The development of breeding populations in Greylag Goose (Anser anser), Canada Goose (Branta canadensis), and Egyptian Goose (Alopochen aegyptiacus) in the Hamburg report area from 1990 to 2002. Hamburger Avifaunistische Beiträge 32: 153-186. (German with English summary).

Kurlavičius, P. (ed.). 2006. Lithuanian breeding bird atlas. Lutute, Vilnius.

Leito, A. \& Truu, J. 2008. Development of the Barnacle Goose Branta leucopsis population in Estonia. Vogelwelt 129: 239-243.

Lerner, H. 2009. Vitkindad gås Branta leucopsis. Pp. 77 in Fågelåret 2008 (Bentz, P.-G. \& Wirdheim, A., eds.). SOF, Halmstad.

Lever, C. 2005. Naturalised birds of the world. T. \& A.D. Poyser, London.

Lund, H.M.K. 1966. Snøgås fra Svartehavet. Norsk Natur 2: 108 .

Lysenko, V.I. 1991. Fauna of Ukraine. Birds (Anseriformes). Vol. 5. No. 3. Institute of Zoology, Academy of Sciences USSR. Naukova Dumka, Kiev. (Russian).

Lysenko, V.I. 2001. The current status of Greylag Goose in Ukraine. In Zoological studies in Ukraine at millennium edge. Proceedings of All-Ukrainian Zoological Conference IBI, Krivoi Rog. (Russian).

Lysenko, V. 2004. About status of Anser anser in Ukraine. Programme abstracts, $8^{\text {th }}$ Annual Meeting of the Goose Specialist Group, Odessa.

Magnus Gothus, O. 1555. Historia de Gentibus Septentrionalibus. Rome.

Matias, R., Catry, P., Costa, H., Elias, G., Jara, J., Moore, C.C. \& Tomé, R. 2007. Systematic list of the birds of
Mainland Portugal. Anuário Ornitológico 5: 74-132. (Portuguese with English summary).

Mednis, A. 1983. Anser anser (L.). Pp. 31-32 in Birds of Latvia (Vīksne, J., ed.). Zinātne, Riga. (Russian with English summary).

Medvedev, N.V. 1992. Nesting of Canada Goose (Branta canadensis L.) on the Valaam archipelago of the Ladoga lake. Russian Journal of Ornithology 1: 113-114.

Molina, B. \& Lorenzo, J.A. 2007. Noticiario Ornitológico. Ardeola 54: 389-403.

Molina, B., Lorenzo, J.A. \& López-Jurado, C. 2008. Noticiario Ornitológico. Ardeola 55: 131-151.

Molina, B., Prieta, J., Lorenzo, J.A. \& López-Jurado, C. 2009. Noticiario Ornitológico. Ardeola 56: 345-367.

Moreno Gaztambide, J.I. 1993. Una pareja de ansares cría por primera vez en Navarra. Federcaza 96: 39-40.

Náttúrfræðistofnun Íslands 2000. Válisti 2. Fuglar. Reykjavik.

Neubauer, W. 1983. Der Einflug der Kanadagans im Winter 1978/79 ins Binnenland der DDR. Falke 30: 378-383.

Nilsson, L. 2009. International waterfowl and goose counts in Sweden. Annual report 2008/09. 69 pp. Department of Ecology, Lund University. (Swedish with English summary).

Nilsson, L., Follestad, A., Koffijberg, K., Kuiken, E., Madsen, J., Mooij, J., Mouronval, J.B., Persson, H., Schricke, V. \& Voslamber, B. (1999) Greylag Goose Anser anser: Northwest Europe. Pp. 182-201 in Goose populations of the Western Palearctic. (Madsen, J., Cracknell, G. \& Fox, T., eds.). Wetlands International Publication No. 48. Wetlands International \& National Environmental Research Institute, Wageningen \& Rønde.

Nilsson, S. 1858. Skandinavisk Fauna. Foglarna. Vol. 2. Gleerups Förlag, Lund.

Ogilvie, M. \& the Rare Breeding Birds Panel. 2000. Nonnative birds breeding in the United Kingdom in 1998. British Birds 93: 428-433.

Ottvall, R. 2008. Feasibility study of catching and genetic screening of Swedish Lesser White-fronted Geese Anser erythropus. Report, 36 pp. Department of Ecology, Lund University.

Owen, M., Callaghan, D. \& Kirby, J. 2006. Guidelines on Avoidance of Introductions of Non-native Waterbird Species. AEWA Technical Series No. 12. Bonn, Germany.

Pennington, M.G. 2000. Greylag Geese breeding in Shetland. Scottish Birds 21: 27-33.

Randler, C. 2000. Hybrid wildfowl (Anseriformes) in Western Central Europe - distribution, occurrence and causes. Ökologie der Vögel / Ecology of Birds 22: 1-106. (German with English summary).

Riols, C. 1994. Oie cendrée Anser anser. Pp. 120-121 in Novel Atlas des Oiseaux Nicheurs de France 1985-1989 (Yeatman-Berthelot, D. \& Jarry, G., eds.). Société ornithologique de France, Paris.

Robyns De Schneidauer, Th. 1968. La population expérimentale d'oies cendrées dans la Réserve du Zwin. Ardea 56: 228-247. (French with English summary).

Rowell, H.E., Ward, R.M., Hall, C. \& Cranswick, P.A. 2004. The Naturalised Goose Survey 2000. The Wildfowl \& Wetlands Trust, Slimbridge.

Ruokonen, M., Andersson, A.-C. \& Tegelström, H. 2007. Using historical captive stocks in conservation. The case of the lesser white-fronted goose. Conservation Genetics 
8: 197-207.

Rutschke, E. 1997. Wildgänse: Lebensweise-Schutz-Nutzung. Parey, Berlin.

Sadura, A. \& Cooke, F. 1982. On European Occurrence of Lesser Snow Goose from Canada. Dutch Birding 4: 37-40.

Sharrock, J.T.R. 1976. The Atlas of Breeding Birds in Britain and Ireland. British Trust for Ornithology, Tring.

Sharrock, J.T.R. \& the Rare Breeding Birds Panel 1982. Rare breeding birds in the United Kingdom. British Birds 75: $154-178$.

SOF. 1990. Sveriges fåglar. $2^{\text {nd }}$ ed. Stockholm.

SOF. 2002. Sveriges fåglar. $3^{\text {rd }}$ ed. Stockholm.

Sol, D., Blackburn, T., Cassey, P., Duncan, R. \& Clavell, J. 2005. The Ecology and Impact of Non-indigenous Birds. Pp. 13-35 in Handbook of the Birds of the World. (del Hoyo, J., Elliott, A. \& Christie, D.A., eds.). Vol. 10. Cuckoo-shrikes to Thrushes. Lynx Ediciones, Barcelona.

Švažas, S., Stanevičius, V. \& Čepulis, M. 1997. The status, numbers and distribution of swans and geese in Lithuania. Acta Zoologica Lituanica, Ornithologia 6: 66-78.

Švažas, S., Drobelis, E., Balčiauskas, L. \& Raudonikis, L. 1999. Important wetlands in Lithuania. OMPO Vilnius, Vilnius.

Svensson, S., Svensson, M. \& Tjernberg, M. 1999. Svensk fågelatlas. Vår Fågelvärld, supplement 31, Stockholm.

Sørensen, S. \& Jensen, J.-K. 1991. Sjældne fugle på Færøerne i 1988 og 1989. Dansk Ornithologisk Tidsskrift 85: 35-40.

Teixeira, R.M. 1979. Atlas van de Nederlandse Broedvogels. Vereniging tot Behoud van Natuurmonumenten in Nederland, 's-Graveland.

Vermeersch, G., Anselin, A., Devos, K., Herremans, M., Stevens, J., Gabriéls, J. \& Van der Krieken, B. 2004. Atlas van de Vlaamse broedvogels 2000-2002. Mededelingen van het Instituut voor Natuurbehoud 23, Brussels.

Vinicombe, K. 2007. Cackling Goose. Birdwatch 175: 2831.

Voslamber, B., van der Jeugd, H. \& Koffijberg, K. 2010. Breeding goose populations in The Netherlands. De Levende Natuur 111: 40-44. (Dutch with English summary).

Zedlitz, O.G. 1914. Ornithologische Reisebilder aus NordAlgerien. Journal für Ornithologie 62: 110-134.

Zubko, V.M. \& Havrilenko, V.S. 2002. Results of 100 years ringing of birds reared in Ascania Nova. Pp. 117-134 in Bird ringing and marking in Russia and adjacent countries 1988-1999 (Dobrynina, I.N., ed.). Moscow. (Russian).

\section{Sammanfattning}

Under de senaste femtio åren har gäss som i Europa återfinns i naturen endast tack vare människan, introducerade avsiktligt eller av misstag, ökat flera gånger om, i antal arter, i antal populationer och i antal individer. På grund av det inflytande dessa gäss kan ha på dels biologisk mångfald och dels mänsklig aktivitet har de tilldragit sig ett växande intresse under de senaste två decennierna. Den biologiska mångfalden kan påverkas genom introduktion av främmande gener, hybridisering, kon- kurrens, sjukdomsspridning eller habitatförändringar, medan påverkan på mänsklig aktivitet till sin karaktär kan vara antingen ekonomisk eller estetisk. Det som oftast sysselsätter tjänstemän idag är skördeskador inom jordbruket, nedsmutsning av parker, badplatser och golfbanor samt attacker av gäss i rekreationsområden. Dessutom finns det en oro för att en negativ inställning bland allmänheten till dessa gäss skall spilla över på deras vilda släktingar, resulterande $i$ en lägre acceptans för gäss $i$ allmänhet.

En hel del har under åren gjorts för att samla in kunskap om de naturaliserade gässen, men för den som söker kunskap på detta område är det ofta svårt att finna rapporterna, och ännu svårare att bedöma deras tillförlitlighet. Avsikten med denna rapport var att dels utreda vilka gäss som bör räknas som naturaliserade och dels göra en sammanställning av grundläggande data om samtliga populationer av naturaliserade gäss i Europa.

I Appendix redovisas samtliga populationer nationsvis, eftersom det vanligtvis är på den nivån som inventeringar och räkningar sker. För Belgium gjordes dock en uppdelning på tre regioner. För grågås och vitkindad gås redovisas även ett antal lokala populationer.

Textdelen ägnas nästan uteslutande åt att artvis reda ut vilka populationer som bör räknas som naturaliserade. Definitioner till trots är detta långt ifrån alltid självklart. Dessutom råder för närvarande en tendens att räkna in allt fler naturaliserade populationer bland de vilda. Problemen beror på vilken geografisk referensram som används, ursprunget för de individer som etablerar en ny population samt förekomsten av främmande gener. De introducerade arterna svangås, stripgås, snögås, dvärgsnögås, kejsargås, dvärgkanadagås och kanadagås är i detta avseende inget problem, varför texten för dessa arter framförallt redovisar sporadiska häckningar samt hur antalet individer i vissa populationer beräknats.

Inom delar av Dalarna, Hälsingland och Härjedalen där arten inte längre häckade släpptes totalt 376 färgringmärkta sädgåsgässlingar med kanadagäss som fosterföräldrar ut under åren 1974-1991. De utsläppta gässen övervintrade vid Foteviken, mindre än tre kilometer från var GSG12 hölls. Efter det att de märkta fåglarna dött och arten slutat att övervintra vid Foteviken, gick det inte längre att följa upp projektet. Om sädgäss som därefter konstaterats häcka i utsättningsområdena varit ättlingar till de utsatta fåglarna, vilda fåglar från närliggande områden eller en blandning av dessa båda kategorier är okänt. Sannolikt var detta projekt en 
framgångsrik beståndsförstärkning. Samma resonemang kan föras beträffande det svenska fjällgåsprojektet. Dagens fjällgäss består med största sannolikhet av en blandning av utsläppta och vilda fåglar och utgör därmed den sista spillran av den en gång så talrika skandinaviska fjällgåspopulationen.

Grågåsen uppvisar flest exempel på svårigheten att skilja mellan naturaliserade och vilda populationer. Efter att under första halvan av 1900-talet varit nere på sin lägsta nivå, sett till utbredning och antalet individer i Europa, hjälpte bl.a. omflyttningar och utsättningar till att arten återhämtade sig. Efterhand som gränsen mellan vilda och naturaliserade populationer alltmer suddats ut, har tendensen gått mot att betrakta alltfler naturaliserade populationer som vilda. I texten används Färöarna som exempel på detta, medan Ukraina exemplifierar betydelsen av geografisk referensram - den ukrainska populationen som helhet är beståndsförstärkt medan ett flertal lokala populationer kan vara naturaliserade. I Inre Oslofjorden sattes såväl norska som svenska grågäss ut, dvs. en blandning av raserna sylvestris och anser. Till följd därav är det idag nästintill omöjligt att avgöra om gässen i fjordens närmaste omgivningar utgörs av vilda fåglar eller ättlingar till de utsatta samt till vilken ras eller rasblandning dessa hör. Till Kalmarsund infördes 1929 sex grågäss av den ostliga rasen rubrirostris och till Zwin i Belgien 1955 likaså sex individer. Från Kalmarsund omflyttades under årens lopp ett antal ägg och ungar till olika delar av Sverige och från Zwin flyttades fåglar till bland annat England, Nederländerna och Frankrike. Denna spridning av rubrirostris är sannolikt förklaringen till att vi idag i Sverige och Nederländerna finner grågäss med orangeröda eller röda näbbar, vilket inte var fallet i mitten av 1800-talet, då alla grågäss hade orange näbbar. Det oklara begreppsläget beträffande hur man ska se på förekomsten av främmande gener gjorde dock att ingen population togs med i Appendix av den anledningen. Grågässen som häckar i Öster-Malma-området utgör ett specialfall av naturalisering, eftersom de endast kan urskiljas tack vare att de övervintrar på en lokal som ligger utanför artens traditionella flyttningsvägar. En logisk förklaring till hur detta har uppstått kan ges tack vare den halsringmärkning som skedde vid Öster-Malma åren 1984-1992. Grågåsen återetablerades vid Öster-Malma under åren 1970-1975 framförallt genom att ägg togs från sydöstra Sverige och placerades under kanadagäss, vilka därefter fungerade som fosterföräldrar. Under den första stränga vintern efter återetableringen, sannolikt 1978/1979, tvingades grågässen söderut från sitt dittillsvarande vinterkvarter någonstans vid södra Östersjön, och de fann då av en tillfällighet Lac du Der Chantecoq, ett vattenmagasin 15 mil öster om Paris, en lokal som de därefter förblivit trogna. Även övervintrarna vid Camargue utgörs sannolikt av naturaliserade gäss, ty även den lokalen ligger utanför de traditionella flyttningsvägarna.

Soepgans används i Nederländerna som samlande begrepp för friflygande individer av alla former av domesticerade grågäss, hybrider mellan sådana gäss och såväl grågäss som andra arter samt alla individer av domesticerade former av svangås. I Appendix rapporteras dessa gäss som Anser anser domesticus. För att göra resultaten jämförbara användes denna definition även för uppgifter från Storbritannien, Irland och Belgien.

Utsättningar och rymningar förutan hade det med största sannolikhet inte funnits några kolonier av vitkindad gås $i$ tempererade områden idag. Nio lokala populationer och en regional, var och en kopplad till en lokal med friflygande tamfåglar, finns med i Appendix. Den största av dessa, på den danska ön Saltholm, ligger endast 12 kilometer från Malmö. Det har inte bevisats att kolonin på Saltholm grundades av förrymda fåglar. Tvärtom betraktas den vanligtvis som ett resultat av en expansion av populationerna på Gotland och Öland. Med hänsyn till de långa spridningsavstånd som dokumenterats bland friflygande vitkindade gäss skulle även andra lokala populationer än de nio kunnat tas med i Appendix, tillsammans med populationer som avsiktligt introducerats. Det första svenska häckningsfyndet till exempel, i Härjedalen 1952, gjordes av fåglar som rymt från fångenskap i Skottland. Ett ständigt ökande antal friflygande vitkindade gäss från 1960-talet och framåt sammanfaller ganska väl med etablerandet av kolonier i östersjöområdet. Vitkindade gäss som häckar på Island, Gotland, Öland, i Estland och längs med den tyska kusten räknas ofta som vilda. Eftersom dessa kolonier inte har någon känd koppling till någon lokal med friflygande fångna fåglar togs de ej med i Appendix men väl i Tabell 1.

Eftersom uppgift om antalet individer saknas från åtminstone de senaste två åren för en tredjedel av de nationella populationerna, samtidigt som flera av dessa varit inne i en fas av snabb tillväxt sedan sent 1990-tal, är det ingen överdrift att påstå att totala antalet naturaliserade gäss i Europa vid häckningsperiodens slut år 2009 uppgick till drygt 800.000 (Tabell 1). Drygt $99 \%$ av det totala antalet kom från endast tre arter: kanadagås, grågås och vitkindad gås. Till dessa skall läggas ett okänt antal hybrider. 
Appendix. Naturalised populations of Anser and Branta geese in Europe. Year of first breeding (or year of introduction, if year of first breeding was unknown), monitoring scheme (M), latest count/estimate of number of pairs (year within brackets), latest count/estimate of number of individuals (year within brackets; two digits given for years within the 2000s), and 1-3 data sources are given for each population. A horizontal bar indicates lack of data. Monitoring schemes and data sources are listed below the table.

Naturaliserade populationer av Anser- och Branta-gäss i Europa. År för första häckning (eller introduktionsår om år för första häckning är okänt), övervakningsprogram (M), senaste uppgift om antalet häckande par (årtal inom parentes; endast två siffror anges för år på 2000-talet), senaste uppgift of antalet individer (årtal inom parentes), och 1-3 datakällor anges för varje population. Minustecken anger att uppgift saknas. Övervakningsprogram och datakällor listas under tabellen.

\begin{tabular}{|c|c|c|c|c|c|c|}
\hline $\begin{array}{l}\text { Taxon } \\
\text { Taxon }\end{array}$ & $\begin{array}{l}\text { Population } \\
\text { Population }\end{array}$ & $\begin{array}{l}\text { First } \\
\text { Första }\end{array}$ & $\begin{array}{l}\mathbf{M} \\
M\end{array}$ & $\begin{array}{l}\text { No. of pairs } \\
\text { Antal par }\end{array}$ & $\begin{array}{l}\text { No. of birds } \\
\text { Antal individer }\end{array}$ & $\begin{array}{l}\text { Sources } \\
\text { Källor }\end{array}$ \\
\hline A cygnoides & Germany & 1967 & $\mathrm{a}$ & $15-20(05)$ & - & 5 \\
\hline A cygnoides & Netherlands & - & $\mathrm{b}$ & $150(08)$ & $500(05)$ & $34,42,68$ \\
\hline A cygnoides & Belgium & - & - & $10(02)$ & - & 63 \\
\hline A serrirostris & Netherlands & 1993 & $\mathrm{~b}$ & $2(08)$ & $5(09)$ & $34,67,68$ \\
\hline A brachyrhynchus & France & 2001 & - & - & $14(03)$ & 19 \\
\hline A a albifrons & Germany & 2001 & $\mathrm{a}$ & $4(05)$ & - & 5,73 \\
\hline A a albifrons & Netherlands & 1980 & $\mathrm{~b}$ & $745(08)$ & 1999 (09) & $34,66,68$ \\
\hline A a albifrons & Belgium & - & - & $3-6(02)$ & - & 63 \\
\hline A a flavirostris & United Kingdom & - & $\mathrm{cd}$ & $1(03)$ & - & 29 \\
\hline A erythropus & Netherlands & 2002 & $\mathrm{~b}$ & $3(08)$ & $7(09)$ & $13,34,69$ \\
\hline$A$ anser & Iceland & 1957 & - & - & $992(09)$ & 52 \\
\hline A anser & United Kingdom & $1930 \mathrm{~s}$ & de & - & $50,000(08)$ & $16,46,48$ \\
\hline$A$ anser & Ireland & 1967 & $\mathrm{f}$ & - & $1555(08)$ & $14,15,45$ \\
\hline$A$ anser & Inner Oslofjord, NO & 1979 & g & $87(09)$ & - & 11 \\
\hline$A$ anser & Norway & $1960 \mathrm{~s}$ & - & $>87(09)$ & - & \\
\hline$A$ anser & Öster-Malma, SE & 1965 & $\mathrm{~h}$ & - & $3230(08)$ & 17 \\
\hline$A$ anser & Malmö, SE & - & $\mathrm{i}$ & $<100(09)$ & $>500(09)$ & 9 \\
\hline$A$ anser & Sweden & 1930 & - & - & $>4000(08)$ & 60 \\
\hline$A$ anser & Hamburg, DE & $1960 \mathrm{~s}$ & s & $143(09)$ & $\geq 700(09)$ & 28,37 \\
\hline A anser & C. Neckar valley, DE & 1984 & $\mathrm{r}$ & $11(08)$ & $234(08)$ & 75 \\
\hline$A$ anser & Germany & - & $\mathrm{a}$ & $5000-5500(05)$ & - & 4,5 \\
\hline$A$ anser & Netherlands & 1961 & $\mathrm{~b}$ & $35,000(08)$ & $189,903(09)$ & $34,68,69$ \\
\hline$A$ anser & Flanders, BE & 1956 & - & $1200-1300(02)$ & - & $18,57,63$ \\
\hline$A$ anser & Wallonia, BE & 1987 & - & $25-31(01-07)$ & - & 31 \\
\hline$A$ anser & Belgium & 1956 & - & $1225-1331(02)$ & - & \\
\hline$A$ anser & France & 1970 & $\mathrm{t}$ & $146-166(08)$ & - & 61 \\
\hline$A$ anser & Switzerland & 1983 & $\mathrm{j}$ & $36(08)$ & - & $59,65,74$ \\
\hline$A$ anser & Austria & 1970 s & - & - & $200-500(09)$ & \\
\hline$A$ anser & Italy & 1984 & - & $>100(09)$ & - & 49,62 \\
\hline$A$ anser & Slovenia & 2007 & - & $2(08)$ & - & \\
\hline$A$ anser & Náměšt' n Oslavou, CZ & 1977 & - & $18(08)$ & - & 22 \\
\hline$A$ anser & Chomutov, CZ & 1988 & - & $21-24(08)$ & - & 53,55 \\
\hline A anser & Česká Lípa, CZ & 2007 & - & $1(09)$ & - & 54,56 \\
\hline$A$ anser & Czech Republic & 1977 & - & $40-43(08)$ & - & \\
\hline A a domesticus & United Kingdom & - & $\mathrm{cd}$ & - & $841(08)$ & 16,58 \\
\hline A a domesticus & Ireland & - & $\mathrm{f}$ & - & $236(05)$ & 15 \\
\hline A a domesticus & Netherlands & - & $\mathrm{b}$ & $3700-5000(08)$ & $\begin{array}{l}15,000-18,000 \\
(05)\end{array}$ & $34,39,40$ \\
\hline A a domesticus & Belgium & - & - & - & - & 63 \\
\hline A a domesticus & France & - & - & - & - & \\
\hline A indicus & United Kingdom & - & $\mathrm{cd}$ & $2(05)$ & $52(00)$ & $29,30,58$ \\
\hline A indicus & Germany & 1956 & $\mathrm{a}$ & $15-18(05)$ & - & 5 \\
\hline A indicus & Netherlands & 1972 & $\mathrm{~b}$ & $100(08)$ & $350(05)$ & $34,43,68$ \\
\hline A indicus & Flanders, BE & 1989 & - & $25-35(05)$ & $>70(02)$ & $2,6,63$ \\
\hline
\end{tabular}


Appendix. forts

\begin{tabular}{|c|c|c|c|c|c|c|}
\hline$A$ indicus & Wallonia, BE & 2001 & - & $2(01-02)$ & - & 31 \\
\hline$A$ indicus & Belgium & 1989 & - & $25-35(05)$ & $>80(02)$ & \\
\hline$A$ indicus & France & 1999 & - & $3(06)$ & - & 19 \\
\hline A caerulescens & United Kingdom & - & $\mathrm{cd}$ & $8(05)$ & $86(00)$ & $29,30,58$ \\
\hline A caerulescens & Norway & 1981 & $\mathrm{~g}$ & $0(09)$ & $0(09)$ & 10,11 \\
\hline A caerulescens & Germany & 1990 & $\mathrm{a}$ & - & $69(09)$ & 5 \\
\hline A caerulescens & Netherlands & - & $\mathrm{b}$ & $3(08)$ & $6(09)$ & $34,68,69$ \\
\hline A rossii & Netherlands & 2004 & b & $1(08)$ & $2(05)$ & $34,68,69$ \\
\hline A canagica & United Kingdom & 2001 & $\mathrm{~cd}$ & $2(05)$ & $16(08)$ & $16,29,58$ \\
\hline A canagica & Netherlands & - & $\mathrm{b}$ & $5(08)$ & $150(05)$ & $34,68,69$ \\
\hline B leucopsis & Faroe Islands & 1991 & - & 10-12 (09) & - & 32,33 \\
\hline B leucopsis & United Kingdom & - & $\mathrm{cd}$ & $\geq 120(05)$ & $1516(09)$ & $16,29,58$ \\
\hline B leucopsis & Ireland & - & $\mathrm{f}$ & $3(00)$ & $15(00)$ & \\
\hline B leucopsis & Saltholm, DK & 1992 & $\mathrm{k}$ & $1317(08)$ & - & 20 \\
\hline B leucopsis & Denmark & 1989 & $\mathrm{k}$ & $1320(08)$ & - & 20,25 \\
\hline B leucopsis & Inner Oslofjord, NO & 1979 & g & $251(09)$ & - & 11,12 \\
\hline B leucopsis & Norway & 1979 & - & $300-325(09)$ & - & 7,8 \\
\hline B leucopsis & Fjäderholmarna, SE & 1978 & - & $256(09)$ & - & 23 \\
\hline B leucopsis & Vållholmen, SE & 2002 & - & $92(10)$ & - & \\
\hline B leucopsis & NE Scania, SE & 1987 & 1 & $>150(09)$ & - & 50,71 \\
\hline B leucopsis & Lake Yddinge, SE & 1995 & - & $50(09)$ & $400(09)$ & 50 \\
\hline B leucopsis & Malmö, SE & 1987 & $\mathrm{i}$ & $150-200(09)$ & $1967(09)$ & $8,9,51$ \\
\hline B leucopsis & Sweden & 1952 & - & $>1800(09)$ & - & \\
\hline B leucopsis & Turku, FI & 1984 & $\mathrm{~m}$ & $269(09)$ & $2600(09)$ & \\
\hline B leucopsis & Helsinki area, FI & 1989 & $\mathrm{~m}$ & $1300(09)$ & $8600(09)$ & \\
\hline B leucopsis & Finland & 1978 & $\mathrm{~m}$ & $>2000(08)$ & $14,200(09)$ & \\
\hline B leucopsis & Germany & 1995 & $\mathrm{a}$ & $30(05)$ & - & 5 \\
\hline B leucopsis & Netherlands & 1982 & $\mathrm{~b}$ & $8300(08)$ & $33,842(09)$ & $34,44,68$ \\
\hline B leucopsis & Flanders, BE & 1992 & - & $200(05)$ & - & $2,6,63$ \\
\hline B leucopsis & Wallonia, BE & 1994 & - & $<10$ & - & 31 \\
\hline B leucopsis & Belgium & -1992 & - & $200(05)$ & - & \\
\hline B leucopsis & France & 2001 & - & - & $30(06)$ & 19 \\
\hline B leucopsis & Austria & 1996 & - & - & $5-10(09)$ & \\
\hline B hutchinsii & Netherlands & - & $\mathrm{b}$ & $200(08)$ & $500(05)$ & $34,68,69$ \\
\hline B canadensis & Faroe Islands & 1985 & - & $1(09)$ & - & 1,33 \\
\hline$B$ canadensis & United Kingdom & 1665 & de & - & $88,866(00)^{*}$ & $3,30,35$ \\
\hline B canadensis & Ireland & - & $\mathrm{f}$ & - & $>400(00)$ & 15 \\
\hline B canadensis & Denmark & $1930 \mathrm{~s}$ & - & $1(09)$ & - & $1,21,25$ \\
\hline B canadensis & Norway & 1936 & - & $>2000(00)$ & $>15,000(09)$ & 1,27 \\
\hline B canadensis & Sweden & 1933 & $\mathrm{n}$ & $15,000-20,000(09)$ & $100,000(08)$ & $1,47,60$ \\
\hline B canadensis & Finland & 1966 & $\mathrm{o}$ & $7000-8000(09)$ & - & $26,64,70$ \\
\hline B canadensis & Poland & 2005 & $\mathrm{p}$ & $3(09)$ & $\geq 19(09)$ & \\
\hline B canadensis & Germany & $1920 \mathrm{~s}$ & a & $1400-1600(05)$ & $>6000(05)$ & 5,24 \\
\hline B canadensis & Netherlands & 1973 & $\mathrm{~b}$ & $4000(08)$ & 23,798 (09) & $34,38,41$ \\
\hline$B$ canadensis & Flanders, BE & 1973 & - & $2000(05)$ & - & $2,6,63$ \\
\hline B canadensis & Wallonia, BE & 1986 & - & $670-1000(07)$ & - & 31 \\
\hline B canadensis & Brussels, BE & 2002 & - & $>12(04)$ & - & 72 \\
\hline B canadensis & Belgium & 1973 & - & $2682-3012(05)$ & - & \\
\hline B canadensis & Luxembourg & 2002 & $q$ & $5(09)$ & 50-80 (09) & 36 \\
\hline B canadensis & France & 1970 & - & $1125(08)$ & $\geq 4250(08)$ & 19 \\
\hline B canadensis & Austria & 1989 & - & $5-10(09)$ & $30-100(09)$ & \\
\hline B canadensis & Russia & 1987 & - & - & 300 (1991) & 1 \\
\hline
\end{tabular}

$*=$ Number of full-grown individuals at the beginning of the breeding season. Antal fullvuxna individer vid början av häckningssäsongen. 
Monitoring schemes Övervakningsprogram (M)

a. Projektgruppe Neozoen der Deutschen Ornitologen-Gesellschaft; collects population data continuously.

b. SOVON Vogelonderzoek Nederland; summer surveys in 2005 and 2009.

c. Rare Breeding Birds Panel (RBBP); collates annual breeding records since 1996.

d. Wildfowl \& Wetlands Trust (WWT); naturalised goose surveys in 1991 and 2000.

e. Wetland Bird Survey (WeBS); monthly counts of non-breeding birds.

f. Irish Wetland Bird Survey (I-WeBS); monthly counts of non-breeding birds.

g. Norsk Ornitologisk Forening, avdeling Oslo og Akershus (NOF OA); summer surveys annually 1978-1991 and every second year thereafter.

h. Ligue pour la Protection des Oiseaux (LPO); annual mid-winter counts.

i. Skånes Ornitologiska Förening (SkOF); summer surveys annually since 2002.

j. Schweizerische Vogelwarte, Sempach: number of breeding pairs reported annually.

k. Dansk Ornitologisk Forening (DOF); as part of the DATSY programme, number of breeding pairs reported annually up to 2008 .

1. Nordöstra Skånes Fågelklubb; number of breeding pairs reported annually.

m. Finnish Environmental Institute (SYKE); summer surveys + total count in September.

n. Leif Nilsson; national counts in September, October, November and December.

o. Finnish Archipelago Bird Census; summer surveys of 36 census areas comprising 1,700 islands.

p. Alien Species in Poland; data taken from the website of the Polish Rarity Commission.

q. Lëtzebuerger Natur- a Vulleschutzliga (LNVL); population monitored annually.

r. Friederike Woog; number of adults, goslings and non-breeders recorded annually since 2003.

s. Arbeitskreis an der Staatlichen Vogelschutzwarte Hamburg (AKVSW); intensive monitoring of the breeders.

t. Ligue pour la Protection des Oiseaux (LPO); number of breeding pairs reported annually since 1990.

\section{Sources Källor}

1. Andersson, Å., Madsen, J., Mooij, J. \& Reitan, O. 1999. Canada Goose Branta canadensis: Fennoscandia/continental Europe. Pp. 236-245 in Goose Populations of the Western Palearctic. (Madsen, J., Cracknell, G. \& Fox, T., eds.). Wetlands International Publ. No. 48. Wetlands International \& National Environmental Research Institute, Wageningen \& Rønde.

2. Anselin, A. \& Vermeersch, G. 2005. Numbers and distribution of breeding feral geese in Flanders. Oriolus 71 (Supplement): 111-120. (Flemish with English summary).

3. Austin, G.E., Rehfisch, M.M., Allan, J.R. \& Holloway, S.J. 2007. Population size and differential population growth of introduced Greater Canada Geese Branta canadensis and re-established Greylag Geese Anser anser across habitats in Great Britain in the year 2000. Bird Study 54: 343-352.

4. Bauer, H.-G., Bezzel, E. \& Fiedler, W. 2005. Das Kompendium der Vögel Mitteleuropas. Vol. 3. Aula-Verlag, Wiebelsheim.

5. Bauer, H.-G. \& Woog, F. 2008. Non-native and naturalised bird species (neozoa) in Germany, part I: occurrence, population size and status. Vogelwarte 46: 157-194. (German with English summary).

6. Beck, O. \& Anselin, A. 2005. Management of feral geese populations in Flanders. Oriolus 71 (Supplement): 166-169. (Flemish with English summary).

7. Bengtson, R., Bergan, M. \& Andersen, G.S. 1994. Hvitkinngås Branta leucopsis. Pp. 68-69 in Norsk fugleatlas (Gjershaug, J.O., Thingstad, P,G., Eldøy, S. \& Byrkjeland, S., eds.). Norsk Ornitologisk Forening, Klæbu.

8. Bengtsson, K. 2007. Vitkindad gås - det rysk/ baltiska beståndets expansion. Anser 46: $137-$ 162.

9. Bengtsson, K. 2009. Gåsproblematiken i Malmö. Anser 48: 131-133.

10. Bergan, M. 2010. Snøgåsa som hekkefugl i Norge - en epoke er over. Vår Fuglefauna 33: 66-72.

11. Bergan, M. \& Andersen, G.S. 2009. Hekkende sjøfugl $i$ indre Oslofjord, Oslo og Akershus 2009. Report, 29 pp. Norsk Ornitologisk Forening, avdeling Oslo og Akershus, Oslo.

12. Bergan, M. \& Andersen, G.S. 2009. Hekkende sjøfugl i indre Oslofjord, Buskerud 2009. Report, 16 pp. Norsk Ornitologisk Forening, 
avdeling Oslo og Akershus, Oslo.

13. Boer, V. de \& Voslamber, B. 2010. Hoeveel overzomerende ganzen telt Nederland? SOVON-Nieuws 23(2): 3-4.

14. Boland, H. \& Crowe, O. 2008. An assessment of the distribution range of Greylag (Icelandic-breeding \& feral populations) in Ireland. Report, 22 pp. BirdWatch Ireland, Newtownmountkennedy.

15. Boland, H., Crowe, O. \& Walsh, A. 2008. Irish Wetland Bird Study: Results of waterbird monitoring in Ireland in 2006/07. Irish Birds 8: 341-350.

16. Calbrade, N.A., Holt, C.A., Austin, G.E., Mellan, H.J., Hearn, R.D., Stroud, D.A., Wotton, S.R. \& Musgrove, A.J. 2010. Waterbirds in the UK 2008/09: The Wetland Bird Survey. British Trust for Ornithology, Royal Society for the Protection of Birds and Joint Nature Conservation Committee in association with Wildfowl \& Wetlands Trust, Thetford.

17. Deceuninck, B., Maillet, N., Ward, A., Dronneau, C. \& Maheo, R. 2009. Census of Anatidae and coots wintering in France - January 2008. Report, 46 pp. Ligue pour la Protection des Oiseaux, Rochefort. (French with English summary).

18. Devos, K., Vermeersch, G., Anselin, A., Kuijken, E., De Scheemaeker, F., Gabriëls, J. \& Hamelink, W. 2005. Distribution and population development of breeding Greylag Geese Anser anser in Flanders. Oriolus 71 (Supplement): 104-110. (Flemish with English summary).

19. Dubois, P.J. 2007. Invasive bird species in France in 2006. Ornithos 14: 329-364. (French with English summary).

20. Ettrup, H. 2009a. Bramgås Branta leucopsis (yngleforekomst). P. 52 in Fugleåret 2008 (Christiansen, J.S. \& Lange, P., eds.). Dansk Ornitologisk Forening, Copenhagen.

21. Ettrup, H. 2009b. Canadagås Branta canadensis (yngleforekomst). P. 52 in Fugleåret 2008 (Christiansen, J.S. \& Lange, P., eds.). Dansk Ornitologisk Forening, Copenhagen.

22. Fiala, V. 2001. Hnízdění husy velké (Anser anser) na Náměšt'ských rybnících 1977-2000. Zprávy MOS 59: 43-56.

23. Fredriksson, R. \& Tjernberg, M. (eds.) 1996. Upplands fåglar - fåglar, människor och landskap genom 300 år. Fåglar i Uppland, supplement 2, Uppsala.

24. Geiter, O., Homma, S. \& Kinzelbach, R. 2002. Bestandsaufnahme und Bewertung von Neozo- en in Deutschland. Untersuchung der Wirkung von Biologie und Genetik ausgewählter Neozoen auf Ökosysteme und Vergleich mit den potentiellen Effekten gentechnisch Veränderter Organismen. Report, 308 pp. Umweltbundesamt, Berlin. (German with English summary).

25. Grell, M.B. 1998. Fuglenes Danmark. Gads Forlag \& Dansk Ornitologisk Forening, Copenhagen.

26. Hario, M. \& Rintala, J. 2004. Population trends of Mute Swan, the Common Eider and three species of goose on Finnish coasts in 1986-2003. Linnut vuosikirja 2003: 49-57. (Finnish with English summary).

27. Heggberget, T.M. \& Reitan, O. 1994. Kanadagås Branta canadensis. Pp. 66-67 in Norsk fugleatlas (Gjershaug, J.O., Thingstad, P,G., Eldøy, S. \& Byrkjeland, S., eds.). Norsk Ornitologisk Forening, Klæbu.

28. Hoff, H.-J. 2005. A population of Greylag Goose (Anser anser) in Öjendorf/Hamburg. First results of a long-time monitoring of birds marked with coloured rings. Hamburger Avifaunistische Beiträge 33: 157-173. (German with English summary).

29. Holling, M. \& the Rare Breeding Birds Panel. 2007. Non-native breeding birds in the United Kingdom in 2003, 2004 and 2005. British Birds 100: 638-649.

30. Holt, C.A., Austin, G.E., Calbrade, N.A., Mellan, H., Thewlis, R.H., Hall, C., Stroud, D.A., Wotton, S.R. \& Musgrove, A.J. 2009. Waterbirds of the UK 2007/08: The Wetland Bird Survey. British Trust for Ornithology, Wildfowl \& Wetlands Trust, Royal Society for the Protection of Birds \& Joint Nature Conservation Committee, Thetford.

31. Jacob, J.-P., Dehem, C., Burnel, A., Dambiermont, J.L., Fasol, M., Kinet, T. \& Van Der Elst, D. in prep. Atlas des oiseaux nicheurs de Wallonie 2001-2007. Aves \& Ministère de la Région Wallonne, Jambes \& Liège.

32. Jensen, J.-K. 1992. Áhugaverdar eygleiðingar i árinum 1991. Frágreiðing frá Føroya Fuglafrødifelag 6: 5-10.

33. Jensen, J.-K., Bloch, D. \& Olsen, B. 2004. Liste over Fugle der er set på Farøerne / List of Birds seen in the Faroe Islands. $2^{\text {nd }}$ ed. Føroya Náttúrugripasavn, Tórshavn.

34. Jeugd, H.P. van der, Voslamber, B., van Turnhout, C., Sierdsema, H., Feige, N., Nienhuis, J. \& Koffijberg, K. 2006. Overzomerende ganzen in Nederland: grenzen aan de groei? 
Sovon-onderzoeksrapport 2006/02. SOVON Vogelonderzoek Nederland, Beek-Ubbergen. (Dutch with English summary).

35. Kirby, J.S. 1999. Canada Goose Branta canadensis: introduced, United Kingdom. Pp. 228-234 in Goose Populations of the Western Palearctic. (Madsen, J., Cracknell, G. \& Fox, T., eds.). Wetlands International Publ. No. 48. Wetlands International \& National Environmental Research Institute, Wageningen \& Rønde.

36. Konter, A. \& Lorgé, P. 2009. Occurrence and breeding of Canadian Branta canadensis (Linné 1758) and Egyptian Goose Alopochen aegyptiacus (Linné 1766) in Luxenbourg. Regulus Wissenschaftliche Berichte 24: 49-54. (German with English summary).

37. Kreutzkamp, I. 2003. The development of breeding populations in Greylag Goose (Anser anser), Canada Goose (Branta canadensis), and Egyptian Goose (Alopochen aegyptiacus) in the Hamburg report area from 1990 to 2002. Hamburger Avifaunistische Beiträge 32: 153186. (German with English summary).

38. Lensink, R. 1996. The rise of exotic species in the Dutch avifauna; past, present and future. Limosa 69: 103-130. (Dutch with English summary).

39. Lensink, R. 1998. Does the Domestic Goose Anser anser forma domestica, as a descendant of the Greylag Goose Anser anser, live its own life in The Netherlands? Limosa 71: 49-56. (Dutch with English summary).

40. Lensink, R. 2002a. Soepgans Anser anser forma domesticus. Pp. 100-101 in Atlas van de Nederlandse Broedvogels 1998-2000 (SOVON Vogelonderzoek Nederland). Nederlandse Fauna 5. Nationaal Natuurhistorische Museum Naturalis, Koninklijke Nederlandse Natuurhistorische Vereniging \& European Invertebrate Survey-Nederland, Leiden. (Dutch with English summary).

41. Lensink, R. 2002b. Grote Canadese Gans Branta canadensis. Pp. 104-105 in Atlas van de Nederlandse Broedvogels 1998-2000 (SOVON Vogelonderzoek Nederland). Nederlandse Fauna 5. Nationaal Natuurhistorische Museum Naturalis, Koninklijke Nederlandse Natuurhistorische Vereniging \& European Invertebrate Survey-Nederland, Leiden. (Dutch with English summary).

42. Lensink, R. 2002c. Zwaangans Anser cygnoides. P. 501 in Atlas van de Nederlandse Broedvogels 1998-2000 (SOVON Vogelonderzoek
Nederland). Nederlandse Fauna 5. Nationaal Natuurhistorische Museum Naturalis, Koninklijke Nederlandse Natuurhistorische Vereniging \& European Invertebrate Survey-Nederland, Leiden. (Dutch with English summary).

43. Lensink, R. \& van Horssen, P. 2002. Indische Gans Anser indicus. Pp. 102-103 in Atlas van de Nederlandse Broedvogels 1998-2000 (SOVON Vogelonderzoek Nederland). Nederlandse Fauna 5. Nationaal Natuurhistorische Museum Naturalis, Koninklijke Nederlandse Natuurhistorische Vereniging \& European Invertebrate Survey-Nederland, Leiden. (Dutch with English summary).

44. Meininger, P.L. 2002. Brandgans Branta leucopsis. Pp. 106-107 in Atlas van de Nederlandse Broedvogels 1998-2000 (SOVON Vogelonderzoek Nederland). Nederlandse Fauna 5. Nationaal Natuurhistorische Museum Naturalis, Koninklijke Nederlandse Natuurhistorische Vereniging \& European Invertebrate Survey-Nederland, Leiden. (Dutch with English summary).

45. Merne, O.J. 1986. Greylag Geese in Ireland. March 1986. Irish Birds 3: 207-214.

46. Mitchell, C. \& Hall, C. 2010. Monitoring of geese in the UK. Results 2009/10. Goose Bulletin 11: 28-32.

47. Nilsson, L. 2009. International waterfowl and goose counts in Sweden. Annual report 2008/09. 69 pp. Department of Ecology, Lund University. (Swedish with English summary).

48. Owen, M. \& Salmon, D.G. 1988. Feral Greylag Geese Anser anser in Britain and Ireland, 1960-1986. Bird Study 35: 37-45.

49. Perco, F. 1991. Recent changes in size of goose populations in Italy. Ardea 79: 169-172.

50. Persson, H. 1997. Breeding of the Barnacle Goose Branta leucopsis in Skåne, 1986-1996. Anser 36: 11-15. (Swedish with English summary).

51. Persson, H. 1998. Den vitkindade gåsens etablering i Skåne; kompletterande uppgifter. $A n$ ser 37: 118-120. (Swedish with English summary).

52. Petersen, Æ. 1998. Íslenskir fuglar. Vaka-Helgafell, Reykjavík.

53. Podhrazský, M. 2006. Shrnutí a předběžné výsledky projektu "Límcování hus na Chomutovsku, Mostecku a Lounsku". Fauna Bohemiae Septentrionalis 30: 45-50.

54. Podhrazský, M. 2007. Reintrodukce husy velké (Anser anser) na Českolipsku. Fauna Bohemiae Septentrionalis 31: 17-56. 
55. Podhrazský, M. 2009a. Monitoring polodivoké populace husy velké (Anser anser) v severozápadních Čechách. Aythya 2: 100-101.

56. Podhrazský, M. 2009b. Vývoj populace husy velké (Anser anser) na Ceskolipsku. Fauna Bohemiae Septentrionalis 33: 39-44.

57. Robyns De Schneidauer, Th. 1968. La population expérimentale d'oies cendrées dans lar Réserve du Zwin. Ardea 56: 228-247. (French with English summary).

58. Rowell, H.E., Ward, R.M., Hall, C. \& Cranswick, P.A. 2004. The Naturalised Goose Survey 2000 . WWT, Slimbridge.

59. Schmid, H., Luder, R., Naef-Daenzer, B., Graf, R. \& Zbinden, N. 1998. Schweizer Brutvogelatlas. Verbreitung der Brutvögel in der Schweiz und in Fürstentum Liechtenstein 1993-1996. Schweizerische Vogelwarte, Sempach.

60. Svensson, S., Svensson, M. \& Tjernberg, M. 1999. Svensk fågelatlas. Vår Fågelvärld, supplement 31, Stockholm.

61. Tiné, R. 2009. Oie cendrée Anser anser (VU). P. 155 in Rare and endangered breeding birds in France in 2008 (Aurélie de Seynes \& species-coordinators). Ornithos 16: 153-184. (French with English summary).

62. Utmar, P. 1999. Oca selvatica Anser anser. Pp. 62-64 in Gli uccelli della provincia de Gorizia (Parodi, R., ed.). Publication No. 42. Museu Friulano de Storia Naturale, Udine.

63. Vermeersch, G., Anselin, A., Devos, K., Herremans, M., Stevens, J., Gabriéls, J. \& Van Der Krieken, B. (eds.) 2004. Atlas van de Vlaamse broedvogels 2000-2002. Mededelingen van het Instituut voor Natuurbehoud 23, Brussel.

64. Vikberg, P. \& Moilanen, P. 1985. Kanadanhanhen tarhaus - ja istutushistoria Souomessa. Soumen Riista 32: 50-56. (Finnish with English summary).

65. Volet, B. \& Gerber, A. 2009. Rare and unusual records of breeding, migrating and wintering bird species in Switzerland, 2008. Der Ornithologische Beobachter 106: 401-418. (German with English summary).

66. Voslamber, B. 2002a. Kolgans Anser albifrons. Pp. 96-97 in Atlas van de Nederlandse Broed- vogels 1998-2000 (SOVON Vogelonderzoek Nederland). Nederlandse Fauna 5. Nationaal Natuurhistorische Museum Naturalis, Koninklijke Nederlandse Natuurhistorische Vereniging \& European Invertebrate Survey-Nederland, Leiden. (Dutch with English summary).

67. Voslamber, B. 2002b. Toendrarietgans Anser serrirostris. P. 501 in Atlas van de Nederlandse Broedvogels 1998-2000 (SOVON Vogelonderzoek Nederland). Nederlandse Fauna 5. Nationaal Natuurhistorische Museum Naturalis, Koninklijke Nederlandse Natuurhistorische Vereniging \& European Invertebrate Survey-Nederland, Leiden. (Dutch with English summary).

68. Voslamber, B., van der Jeugd, H. \& Koffijberg, K. 2007. Numbers, trends and distribution of breeding goose populations in the Netherlands. Limosa 80: 1-17. (Dutch with English summary).

69. Voslamber, B., van der Jeugd, H. \& Koffijberg, K. 2010. Breeding goose populations in The Netherlands. De Levende Natuur 111: 40-44. (Dutch with English summary).

70. Väisänen, R.A, Lammi, E. \& Koskimies, P. 1998. Muuttuva pesimälinnusto. Otava, Keuruu. (Finnish with English summary).

71. Waldermarsson, N. 2009. Inventering av häckfåglar i nordöstra Skånes skärgård under 2009. Spoven 33: 147-153.

72. Weiserbs, A. \& Jacob, J.-P. 2007. Oiseaux nicheurs de Bruxelles 2000-2004: répartition, effectifs, évolution. Aves, Liège.

73. Wink, M., Dietzen, C. \& Gießing, B. 2005. Die Vögel des Rheinlandes. Atlas zur Brutund Wintervogelverbreitung 1990-2000. Beiträge Avifauna Nordrhein-Westfalen, Vol. 36. Verlag NIBU, Neunkirchen.

74. Winkler, R. 1999. Avifaune de Suisse. Nos Oiseaux, Supplement 3.

75. Woog, F., Schmolz, M. \& Lachenmaier, K. 2008. Population trend of feral Greylag Goose (Anser anser) in Stuttgart (southwest Germany). Ornithologische Jahreshefte Baden-Württemberg 24: 141-146. (German with English summary). 